\title{
Multipel representasi tipe nature of models (NoM) dalam buku ajar biologi kelas XI semester 1
}

\author{
Riyadhotus Sholihah $^{1^{*}}$, Fenny Roshayanti ${ }^{2}$, Ipah Budi Minarti ${ }^{3}$ \\ Program Studi Pendidikan Biologi, Universitas PGRI Semarang, \\ Jl. Sidodadi Timur No. 24, Semarang, 50.232 \\ 1 riasolihah3@gmail.com* \\ *korespondensi penulis
}

\begin{abstract}
Abstrak
Penelitian ini berjudul "Multipel Representasi Tipe Nature of Models (NoM) dalam Buku Ajar Biologi Kelas XI Semester 1". Penelitian ini bertujuan untuk mengetahui pola penggunaan tipe model Nature of Models (NoM) yang terdapat dalam buku ajar biologi kelas XI Semester 1. Pendekatan penelitian yang digunakan dalam penelitian ini adalah deskriptif. Sampel dalam penelitan ini adalah buku yang dominan digunakan di SMA N se-Kota Semarang pada buku ajar biologi kelas XI Semester 1. Instrumen yang digunakan dalam penelitian ini yaitu lembar observasi dalam bentuk isian dan checklist untuk mengidentifikasi tipe model NoM yang terdapat dalam buku ajar biologi. Data yang telah didapatkan dideskripsikan berdasarkan tipe-tipe model NoM. Hasil penelitian menunjukkan tipe model skala paling banyak dengan frekuensi 151 atau $54,7 \%$ dibandingkan model matematika dan simulasi yang memiliki frekuensi 3 atau 1\%. Hal ini sesuai dengan karakteristik ilmu biologi yang memiliki cakupan materi berupa abstrak dengan ukuran yang beragam diantaranya mikroskopik dan makroskopik. Sehingga model skala lebih dominan daripada model matematika dan simulasi.
\end{abstract}

Kata kunci: nature of models (NoM), tipe, buku ajar

\section{Abstract}

This research entitled "Multiple Representasions of Nature Models Type in the 1st Semester Biology Textbooks Grade 11th". The aim of this research is to know the use of Nature Models pattern in the $1^{\text {st }}$ semester Biology Textbooks grade $11^{\text {th }}$. This research used descriptive research. The sample of this research was the most used Biology textbook of $1^{\text {st }}$ semester of grade $11^{\text {th }}$ which used by Senior High School in Semarang. This instrument used was observation sheet in essays and checklist form which was used to identify types of Nature Models in Biology Textbooks. In this study, the researcher described the data based on the types of Nature Models. The result showed that the most type of scale model with frequency 151 or $54,7 \%$ compared with mathematical models and simulations had 3 or $1 \%$. This was in accordance with the characteristics of Biological sciences which had abstract material coverage in various sizes including microscopic and macroscopic. So the scale model was more dominant than mathematical and simulation models

Keywords: nature of models, type, textbook

\section{PENDAHULUAN}

Abad 21 dikenal sebagai abad pengetahuan dengan ditandai terjadinya perubahan besarbesaran pada pola kehidupan masyarakat agraris menjadi masyarakat industri dan berlanjut 
ke masyarakat berpengetahuan (Soh, Arsad \& Osman, 2010). Proses ini sebagai tanda terjadinya revolusi industri 4.0 dengan berkembangnya teknologi baru dalam data sains, kecerdasan buatan, robotik, cloud, cetak tiga dimensi dan teknologi nano (Ghufron, 2018). Fenomena tersebut menuntut adanya sumber daya manusia (SDM) yang memiliki berbagai macam keterampilan yaitu kreatif dan inovatif yang ditunjang melalui pendidikan. Pendidikan dapat merubah pola pikir siswa dengan melalui model atau ilustrasi dalam buku ajar.

Model secara empiris dapat menjembatani hukum dan teori, karena model dapat merepresentasikan hal abstrak menjadi suatu objek, peristiwa, proses atau sistem, dan analogi (Boulter dalam Zhang et. al, 2006; Driel et. al 2010). Penggunaan model sangat penting dalam dunia pendidikan di Indonesia yang menggunakan Kurikulum 2013 revisi. Kurikulum 2013 lebih menekankan pada kompetensi siswa dengan strategi pembelajaran menggunakan pendekatan saintifik inquiry. Berdasarkan hasil penelitian sebelumnya model dapat meningkatkan pemahaman siswa sampai $47 \%$ pada materi tentang mekanisme dan proses, dan siswa dapat merekonstruksi teori menjadi model (Bamberger, 2013). Dengan demikian diperlukan penggunaan model-model dalam pembelajaran agar mudah dipahami oleh siswa.

Namun, pada kenyataannya pembelajaran biologi di Indonesia belum sepenuhnya memanfaatkan model. Hal ini sesuai dengan hasil studi programme for internasional student assessment (PISA) tahun 2012, diketahui bahwa kemampuan sains siswa Indonesia sangat rendah. Hasil studi ini dapat dijadikan sebagai acuan mengenai rendahnya kemampuan sains anak-anak Indonesia dibandingkan dengan negara lain. Dalam laporan hasil PISA 2012 (OECD, 2013) dituliskan bahwa rata-rata nilai sains siswa Indonesia adalah 382, dimana Indonesia menempati peringkat 64 dari 65 negara peserta, atau dengan kata lain menempati peringkat kedua terbawah dari seluruh negara peserta PISA. Hal ini dibuktikan dengan rendahnya nilai Ujian Nasional Berbasis Komputer (UNBK) dari setiap wilayah terutama di Kota Semarang. Data penurunan hasil UNBK pada 3 tahun terakhir yaitu 4.43\% (2017), $4.72 \%$ (2016), dan 0,5\% (2015).

Rendahnya nilai UNBK tersebut dipengaruhi oleh kurangnya minat peserta didik terhadap buku teks yang kurang dipahami dan belum memiliki muatan materi yang dapat memotivasi, merangsang, dan melatih kemampuan berpikir tingkat tinggi peserta didik (Abdulkarim, 2007). Buku teks memegang peranan penting dalam proses pembelajaran, kurikulum dan instruksi pembelajaran terutama di Negara berkembang (Chiapetta et al. dalam Ariningrum, 2013). Buku teks yang digunakan mempunyai kelebihan dan kekurangan. Susunan materi pada buku teks telah disajikan urut dan beruntun tetapi tugas - tugas yang 
diberikan kurang variatif dan bahasa yang digunakan kurang dipahami oleh siswa (Nurmutia, 2013). Berdasarkan latar belakang masalah yang telah dipaparkan, maka permasalahan difokuskan pada "Bagaimana Pola Nature of Models (NoM) dalam Buku Ajar Biologi Kelas XI Semester 1 SMA N Di Kota Semarang?". Tujuan penelitian untuk mengetahui pola penggunaan tipe model Nature of Models (NoM) yang terdapat dalam buku ajar biologi kelas XI Semester 1.

\section{METODE}

Metode penelitian yang digunakan dalam penelitian ini yaitu metode deskriptif. Penelitian ini akan mendeskripsikan temuan multipel representasi berdasarkan aspek nature of models (NoM) yang terdapat pada buku ajar biologi kelas XI semester 1. Subjek penelitian berupa sampel buku ajar biologi yang dominan digunakan oleh sekolah di kota Semarang yaitu buku ajar biologi terbitan Erlangga karya Iryaningtyas. Teknik pengumpulan data melalui wawancara terbuka dengan guru MGMP biologi kota Semarang untuk mendapatkan informasi berupa data buku ajar biologi yang dominan digunakan. Instrumen penelitia berupa isian dan lembar checklist yang sesuai dengan penelitian Harrison (2001). Teknik analisis data menggunakan Model Miles and Huberman. Tahap-tahap penelitian ini meliputi tahap reduksi data, display data, dan verifikasi.

\section{HASIL DAN PEMBAHASAN}

Hasil penelitian berupa penggolongan tipe model yang terdapat di buku ajar biologi kelas XI, terdiri atas 6 bab dengan materi sel kode bab S1.1A, struktur dan fungsi jaringan pada tumbuhan kode bab S1.2B, struktur dan fungsi jaringan pada hewan S1.3C, sistem gerak kode bab S1.4D, sistem peredaran darah kode bab S1.5E, dan sistem pencernaan kode bab S1.6F. Penggologan tersebut berdasarkan 8 indikator tipe nature of models (NoM) dalam buku sesuai pada penelitian Harrison (2001), yaitu tipe model skala, analogi - pedagogi, ikon dan simbolik, matematika, teoritis, peta, diagram dan tabel, konsep - proses, dan simulasi. Berikut ini diagram pie kategori tipe nature of models (NoM) dalam buku ajar biologi kelas XI semester 1: 


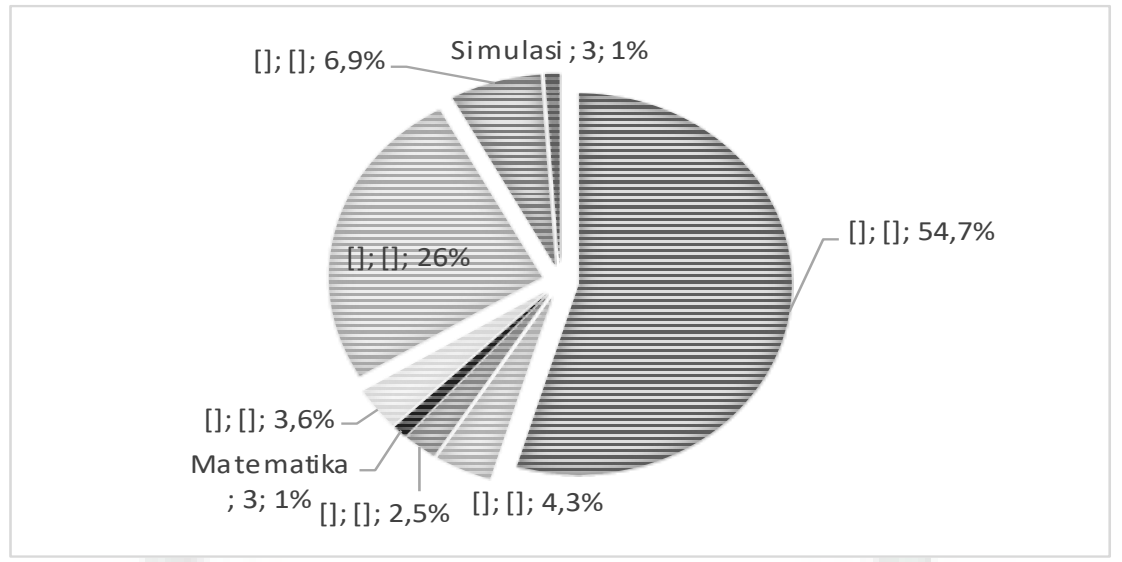

Gambar 1 Diagram Pie Kategori Tipe Nature of Models (NoM) dalam Buku Ajar Biologi Kelas XI Semester 1

Tipe Model NoM merupakan penggambaran sederhana dari teori abstrak yang digambarkan melalui representasi objek, fenomena, proses dan sistem, serta memiliki fungsi sebagai jembatan penghubung antara teori dan fenomena (Oh \& Oh, 2011). Tipe model termasuk ke dalam multipel repesentasi dari eksplanasi pedagogi. Eksplanasi pedagogi merupakan suatu cara untuk menerjemahkan informasi sains yang berasal dari eksplanasi ilmiah agar lebih mudah dipahami oleh siswa serta guru dapat menyampaikan materi dengan mudah. Manfaat adanya eksplanasi pedagogi adalah informasi lebih accessable dan teachable (Siregar et. al dalam Roshayanti, 2002).

Berdasarkan diagram pada gambar 1 menunjukkan penggunaan model berdasarkan aspek NoM secara keseluruhan yang mendominasi adalah model skala. Tipe model yang digunakan untuk mempermudah pemahaman materi. Representasi visual berupa model skala pada buku ajar biologi kelas XI Semester 1 mendominasi hampir setiap Bab dengan frekuensi 151 atau $54,7 \%$ terdiri atas 5 Bab yaitu S1.1A, S1.2B, S1.3C, S1.4D, S1.6F. Model skala tersendiri memiliki karakteristik berupa gambar 2 dimensi, tidak menjabarkan fungsi gambar, dan menampilkan gambar dengan ukuran yang berbeda dari aslinya (Harrison, 2001).

Merujuk pada KD kurikulum 2013, ke lima bab memiliki karakteristik materi yang sama. Materi tersebut berupa struktur sel, jaringan dan organ. Berdasarkan cakupan materi objek berupa abstrak, dengan ukuran mikroskopik, dan tidak dapat dilihat secara langsung. Oleh karena itu, penggunaan model skala diperlukan untuk mempermudah pemahaman siswa. Manfaat dan tujuan penggunaan model ini adalah memperjelas struktur anatomi dan morfologi pada obyek materi sehingga mempermudah pemahaman materi yang sifatnya abstrak dan tidak dapat dilihat secara langsung oleh mata, serta mengurangi adanya kesalahan transfer materi ke siswa. Hal ini sejalan dengan hasil penelitian Sari (2015) visual tipe gambar atau foto dapat membantu siswa dalam memahami materi biologi. 
Selain itu berdasarkan salah satu karakteristik ilmu biologi dilihat dari sifat obyek materi biologi yang memiliki ukuran beragam di antaranya memiliki ukuran mikroskopis misalnya sel, bakteri, virus, jaringan, dll, serta memiliki ukuran makroskopis misalnya tumbuhan dan hewan (Sudarsiman, 2015). Kemudian diperkuat dengan pendapat Sitepu (2012) yang menyatakan bahwa ilustrasi gambar memiliki fungsi sebagai penarik perhatian pembaca dari pada penjabaran narasi teks. Selain itu ilustrasi gambar dapat menimbulkan minat dan motivasi dalam membaca buku ajar. Oleh karena itu penggunaan model skala sangat penting digunakan dalam buku ajar biologi untuk meningkatkan pengetahuan kognitif siswa

Kemudian Model Peta, Diagram, dan Tabel mendapat urutan kedua setelah model skala. Model Peta, Diagram, dan Tabel memiliki frekuensi 71. Model ini ditemukan di semua Bab namun frekuensi paling banyak ditemukan di kode Bab S1.5E frekuensi 19 dengan materi "Sistem Sirkulasi", Materi Sistem sirkulasi ini mencakup struktur jaringan organ pada sistem sirkulasi, bioproses yang terjadi pada sistem sirkulasi (mekanisme pembekuan darah, mekanisme peredaran darah, dan penggolongan darah), dan gangguan pada sistem sirkulasi. Karakteristik materi tersebut banyak membahas proses secara detail dan sistematis, dengan informasi yang luas beruapa faal dan prosesnya maka penggunaan tipe model peta, diagram dan tabel digunakan pada bab ini.

Sedangkan karakteristik model peta, diagram dan tabel berupa visualisasi objek dalam bentuk pola, jalur, hubungan yang tidak dapat dipahami secara langsung (Harrison, 2001). Dikarenakan materi biologi pada kelas XI Semester 1 memiliki materi dengan informasi yang sangat luas tidak hanya menjelaskan tentang struktur anatomi suatu objek materi, namun juga memberikan informasi secara lengkap tentang sel, jaringan, organ dan sistem organ, perbandingan dari setiap objek materi, dan menjelaskan proses faal baik tingkat sel maupun tingkat sistem organ. Hal ini sesuai dengan salah satu karakteristik ilmu biologi yaitu keterjangkauan materi yang luas dan sistematis (Sudarsiman, 2015). Oleh karena itu, tipe model ini dapat menyederhanakan materi yang luas dalam bentuk diagram ataupun tabel.

Model Konsep - Proses, menurut Harrison (2001) menjelaskan konsep sains adalah proses. Jadi dalam menjelaskan proses yang abstrak agar lebih mudah dipahami oleh siswa yang memiliki pola berfikir secara konkret, maka dibutuhkan adanya ilustrasi yang mendukung penjelasan konsep-proses pada materi sains. Penggunaan model konsep - proses dalam buku ajar biologi kelas XI Semester 1 ditemukan dengan frekuensi 19. Frekuensi tertinggi ditemukan pada kode Bab S1.1A yaitu 9. Kode Bab S1.1A memiliki tema bab "Sel". Materi yang menjelaskan proses yang terjadi dalam sel, berupa mekanisme transpor 
membran, reproduksi dan sintesis protein. Proses - proses tersebut tidak dapat dilihat secara langsung, karena sel memiliki ukuran mikroskopik. Hal ini sejalan dengan salah satu karakteristik ilmu biologi yang mengkaji tentang materi abstrak seperti proses - proses metabolisme kimia dalam sel (Sudarsiman, 2015). Oleh karena itu, penggunaan tipe model konsep - proses digunakan.

Perbedaan penjelasan tahapan proses dalam bentuk ilustrasi pada tipe model diagram dengan tipe model konsep proses adalah terletak pada ilustrasi gambar yang digunakan dan adanya garis yang saling menghubungkan, sedangkan tipe konsep-proses memiliki karakteristik yaitu menggunakan ilustrasi gambar dalam setiap tahapan proses dengan dilengkapi adanya penunjuk panah. Tujuannya penggunaan tipe model ini adalah menjelaskan proses - proses yang terjadi dengan memanfaatkan ilustrasi gambar untuk mempermudah pemahaman materi dan mudah diingat oleh siswa sehingga dapat meningkatkan pengetahuan kognitif siswa. Selain itu, ilustrasi gambar berfungsi sebagi jembatan dalam memahami materi biologi berupa proses. Seperti yang diungkapkan oleh Sari (2015) visual tipe gambar dapat membantu siswa dalam memahami konsep biologi. Sedangkan menurut Sitepu (2012) Ilustrasi tersebut membuat konsep lebih konkrit.

Model Analogi Pedagogi, Ilustrasi gambar yang digunakan dalam buku ajar biologi kelas XI tidak hanya menampilkan gambar yang sama persis dengan aslinya, namun menggunakan gambar yang telah dimodifikasi atau analogi gambar. Frekuensi yang ditemukan dalam buku ajar biologi kelas XI pada tipe model analogi pedagogi yaitu 12. Pada kode bab S1.1A lebih dominan menggunakan tipe model ini dengan frekuensi 6. Karakteristik Bab "Sel" adalah materi yang dipelajari berdasarkan hasil kegiatan ilmiah berupa pengamatan di bawah mikroskop. Hasil penelitian atau pengamatan yang dilakukan oleh pakar termasuk ke dalam eksplanasi ilmiah. Pengetahuan konten pedagogi dalam pembelajaran sains sangat penting ditinjau dari konteks wacana para saintis hingga menjadi eksplanasi pedagogik untuk lebih accessible. Accessible menunjukkan materi dapat dijangkau oleh siswa ataupun guru (Siregar et.al dalam Roshayanti, 2002). Penggunaan model analogi-pedagogi mempermudah transformasi materi objek guna membangun pengetahuan siswa dengan baik. Hal ini sejalan dengan pengertian dari penggunaan analogi sebagai transfer informasi dengan materi obyek sedangkan pedagogi digunakan untuk menjelaskan materi nonobservasi (Harrison, 2001).

Model Teoritis, model ini didapatkan dari hasil melakukan kegiatan ilmiah yang dilakukan oleh seorang peneliti. Model ini dapat diterapkan pada ilmu biologi, karena ilmu biologi termasuk ke dalam sains yang terus berkembang dengan adanya kegiatan ilmiah yang dilakukan oleh peneliti. Oleh karena itu model ini muncul dalam buku ajar biologi kelas XI. 
Menurut Harrison (2001), model teoritis merupakan konstruksi manusia yang menggambarkan ide-ide dan teori abstrak. Model tidak hanya mewakili sistem dunia nyata yang meniru alam, namun model ilmiah dapat dibuat dengan cara baru untuk mengekspresikan ide-ide abstrak dalam bentuk teori (Oh \& Oh, 2011). Model teoritis ini merupakan hasil dari eksplanasi ilmiah. Eksplanasi ilmiah berasal dari berbagai macam hipotesis kemudian hasil yang ada dimodelkan dalam bentuk model teoritis atau matematis dan direpresentasikan ke dalam materi objek sebagai bahan pembelajaran (Siregar dkk dalam Rhosayanti, 2002).

Berdasarkan hasil analisis yang telah dilakukan, frekuensi yang ditemukan dalam penggunaan model teoritis yaitu 10, dengan penggunaan paling dominan pada kode Bab SI.2B dengan total 4. memiliki karakteristik konsep berupa kegiatan menganalisis keterkaitan struktur dan jaringan dengan fungsi organ yang dilakukan berdasarkan hasil temuan atau pengamatan secara langsung oleh peneliti. Penggunaan model teoritis dalam buku ajar biologi sangat penting digunakan, karena model ini sebagai point utama dalam pembahasan materi objek, sehingga pembaca dapat memahami informasi dengan cepat dan menajamkan ingatan siswa tentang materi objek. Model teoritis sebagai pelengkap dalam meningkatkan pengetahuan kognitif siswa.

Model Ikon-Simbolik, berdasarkan penjelasan Harrison (2001) model ikon dan simbolik digunakan dalam buku ajar biologi dapat membantu dalam mengingat, model simbolik dapat berupa rumus kimia dan persamaan model simbolik dari senyawa dan reaksi kimia. Penggunaan model ikon simbolik di temukan dalam buku ajar biologi kelas XI dengan frekuensi 7, frekuensi paling banyak di temukan pada kode Bab S1.6F dengan materi “ Sistem Pencernaan". Karakteristik materi ini adalah adanya proses pencernaan yang melibatkan molekul kimiawi sehingga model ini diperlukan dalam memvisualisasikan struktur kimia pada level sub-mikroskopik, Penggunaan model ini dapat membantu siswa dalam mentransformasikan dari level makroskopik menjadi simbolik dan mikroskopis (Davidowitz, et al dalam Sunyono, 2013).

Model Matematika, Model ini jarang digunakan dalam buku ajar biologi, dan lebih banyak ditemukan dalam fisika, matematika, dan kimia, karena representasi visualnya dalam bentuk rumus dan grafik. Sedangkan dalam konsep biologi jarang menggunakan persamaan rumus sebanyak pada konsep materi fisika dan kimia yang merupakan mata pelajaran serumpun yaitu sains. Hal ini dapat dilihat dari hasil temuan penelitian yang telah dilakukan dalam buku ajar biologi kelas XI, model ini hanya ditemukan pada kode Bab S1.6F dengan 
frekuensi 3. Materi pada kode Bab S1.6F yaitu "Sistem Pencernaan" Karakteristik materi tersebut adalah menjelaskan adanya kaitannya nutrisi dengan keadaan tubuh yang menyangkut tentang kebutuhan dan kesimbangan energi yang dibutuhkan dalam tubuh yang membutuhkan adanya rumus matematika untuk menghitung kebutuhan dan keseimbangan energi pada tubuh.

Model matematika menurut penjabaran Harrison (2001) merupakan representasi dari sifat fisik dan proses dalam bentuk persamaan matematika dan grafik yang menggambarkan hubungan konseptual. Jadi model matematika merupakan wujud dari penjabaran suatu konsep dan dituangkan dalam bentuk persamaan rumus. Tujuan adanya model matematika pada kode Bab S1.6F adalah untuk menyederhanakan pernyataan konsep menjadi suatu persamaan matematika, supaya siswa dapat mengerti dan dapat menghitung kondisi kebutuhan dan keseimbangan energi yang dibutuhkan oleh tubuh.

Model Simulasi, model ini dalam buku ajar biologi jarang ditemukan dalam setiap bab, karena model simulasi lebih cocok direpresentasikan dengan menggunakan bantuan animasi ataupun video daripada penggunaan model gambar, namun tanpa adanya model simulasi ini dalam buku ajar biologi akan terasa kurang tepat, karena materi biologi mencakup adanya proses - proses alam yang terjadi sehingga membutuhkam model simulasi sebagai pelengkap model skala, konsep - proses, dan diagram. Berdasarkan hasil analisis model simulasi dalam buku ajar biologi kelas XI ditemukan sebanyak 3 ilustrasi gambar model simulasi yang tersebar dalam kode Bab S1.1A, S1.4D, dan S1.5E. karakteristik materi menjelaskan adanya proses yang terjadi baik tingkat sel, alat gerak, dan sirkulasi darah. Menurut Harrison (2001) model simulasi adalah kombinasi unik dari animasi dan simulasi yang menghasilkan model dinamis. Model simulasi digunakan pada proses yang canggih dan kompleks, penggunaan model simulasi dapat mendorong siswa untuk memvisualisasikan simulasi sebagai realita. Selain itu juga dipengaruhi oleh karakteristik ilmu biologi yang mengkaji tentang materi abstrak seperti proses-proses metabolisme kimiawi, sistem sirkulasi, hormonal koordinasi dan lain-lain, di mana materi tersebut tidak dapat dilihat prosesnya secara langsung (Sudarsiman, 2015). Oleh karena itu penggunaan model simulasi dalam buku ajar tetap ada sebagai pelengkap ilustrasi gambar bagi model sebelumnya untuk menunjang pengetahuan kognitif siswa.

Gambar di bawah ini menunjukkan bahwa materi biologi kelas XI Semester 1 divisualisasikan dengan menggunakan multipel representasi. Jenis-jenis multipel representase merupakan upaya agar konsep dapat tersampaikan dengan baik. 


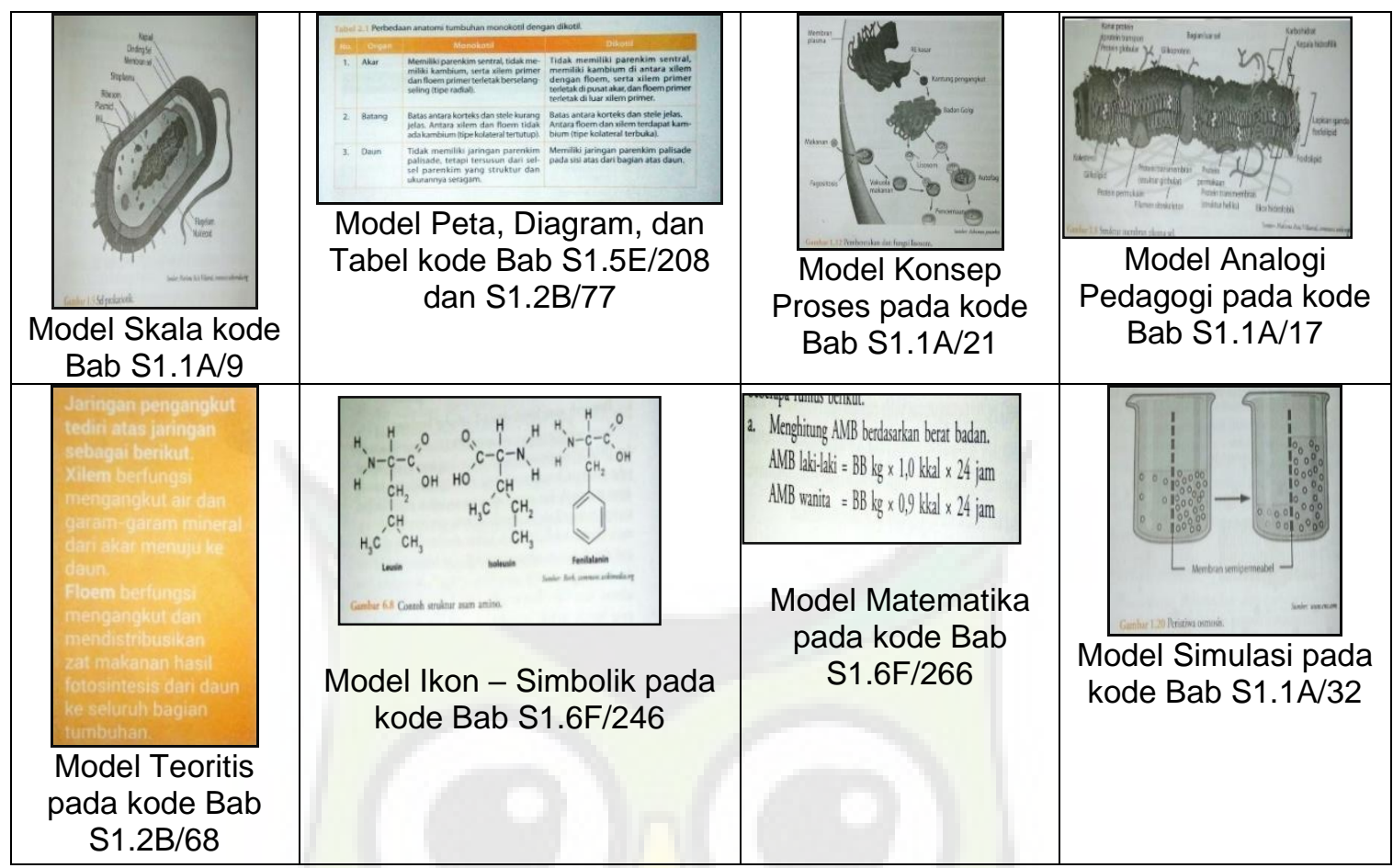

Gambar 2. Multipel representasi Tipe Model NoM (Sumber: buku ajar biologi Erlangga)

Berdasarkan contoh representase model tersebut, aspek pedagogiknya dapat muncul dalam buku ajar. Penggunaan jenis representasi visual yang sesuai dapat meningkatkan pengetahuan kognitif siswa dan literasi ilmiah siswa.

\section{SIMPULAN}

Simpulan Hasil analisis pola tipe Nature of Models (NoM) dalam buku ajar kelas XI semester 1, diketahui dari 276 data penggunaan tipe model NoM untuk mengilustrasikan materi dalam bentuk tipe model skala, model analogi - pedagogi, model ikon dan simbolik, model matematika, model teoritis, peta, diagram dan tabel, model konsep - proses, dan model simulasi. Tipe model yang sering digunakan dalam buku ajar biologi adalah tipe model skala dengan frekuensi 151 atau 54,7\% dan terendah terdapat pada model matematika dan simulasi, masing - masing memiliki frekuensi 3 atau 1\% dari 276 model. Tipe Model NoM sebagai ilustrasi sesuai dengan karakteritik ilmu biologi untuk meningkatkan pengetahuan kognitif siswa. Saran yang dapat diberikan oleh peneliti adalah pemerataan penggunaan model dalam setiap Bab disesuaikan dengan materi dan ilustrasi yang relevan.

\section{REFERENSI}

Abdulkarim, A. 2007. Analisis isi buku teks dan implikasinya dalam membedakan ketrampilan berpikir siswa SMA. Jurnal Forum Kependidikan 26 (2):118-132. 
Ariningrum, Tri Retnani. 2013. Analisis Literasi Ilmiah Buku Teks Pelajaran Biologi SMA. Skripsi tidak diterbitkan. Semarang: Universitas Negeri Semarang

Bamberger, Yeal M., Davis, Elizabeth A. 2013. Middle-School Science Students' Scientific Modelling Performances. Internasional Jiurnal of Science Education. Vol. 35, No. 2

Ghufron, M.A. 2018. Revolusi Industri 4.0: Tantangan, Peluang dan Solusi bagi Dunia Pendidikan. Seminar Nasional dan Diskusi Panel Multididiplin Hasil Penelitian \& Pengabdian kepada Masyarakat. Universitas Indraprasta PGRI, Jakarta, 2 Agustus 2018

Harrison, Allan G. 2001. How do Teachers and Textbook Writers Model Scientific Ideas for Students. Reseach in Science Education. 31: 401 - 435

https://puspendik.kemdikbud.go.id/hasil-un/ [10 November 2018]

Nurbaeti, Indah. 2015. Analisis Kualitas Representasi Visual Bahan Ajar Paket Biologi SMA Kelas XI kultikulum 2013 pada konsep Sistem Koordinasi. Skripsi tidak diterbitkan. Cirebon: Institut Agama Islam Negeri Syekh Nurjati Cirebon

Nurmutia, Halida Eka. 2013. Analisis Materi, Penyajian, dan Bahasa Buku Teks Matematika SMA Kelas X di Kabupaten Rembang Tahun Ajaran 2012/2013. Skripsi tidak diterbitkan. Semarang: Universitas Negeri Semarang.

OECD. 2013. PISA 2012 Assessment and Analytical Framework Mathematics, Raading, Science, Problem Solving and Financial Literacy

Oh, P.S., \& Oh, S. 2011. What Theachers of Science Need to Know About Models: An overview. Internasional journal of Science Education. Vol. 33. No. 8: 1109-1130

Roshayanti, Fenny. 2002. Analisis Fungsi Representasi Materi Subjek Respirasi Sel pada Buku Teks Biologi Umum terhadap Materi Subjek Metabolisme pada Buku Teks Anatomi Fisiologi Tubuh Manusia. Tesis tidak diterbitkan. Bandung: Universitas Pendidikan Indonesia.

Roth, W.-M, \& Pozzer-Ardenghi, L. (2013). Pictures in Education. In Tsui, C. \& Treagust, D. F. (Ed.), Multiple Representations in Biological Education(pp. 3- 18). London: Springer.

Sari. Dwi Wulan. 2015. Analisis Kualitas Buku Paket Biologi Kurikulum 2013 Kelas X Semester 2 Ditinjau dari Aspek Representasi Visual pada Konsep Pencemaran dan Perubahan Lingkungan. Skripsi tidak diterbitkan. Cirebon: IAIN Syekh Nurjati

Sitepu. 2012. Penulisan Buku Teks pelajaran. Bandung: PT. Remaja Resdakarya Offset.

Soh, T., Arsad, N., \& Osman, K. (2010). The relationship of 21st century skills on students' attitude and perception towards physics. Procedia Social and Behavioral Sciences. 7(C). 546-55

Sudarsiman, S. 2015. Memahami Hakekat dan Karakteristik Pembelajaran Biologi dalam Upaya Menjawab tantangan Abad 21 Serta Optimalisasi Implementasi Kurikulum 2013. Jurnal Florea. Vol.2. No.1. Hal 29 - 35

Sunyono, et. al. 2013. Efektivitas Model Pembelajaran Berbasis Multipel Representasi dalam Membangun Model Mental Mahasiswa Topik Stoikiometri Reaksi. Prosiding Seminar Nasional Pendidikan Sains. PPs. Surabaya: Universitas Negeri Surabaya

Zhang,Baohui et.al. 2006. Expert Models and Modeling Processes Associated with a Computer-Modeling Tool.Wiley interScience. Across Content Areas and Within aLearning Progression. International Journal of Science Edu 